УДК: 911.375(477.7)«18/19»

\title{
Вікторія Константінова,
}

директор НДІ Історичної урбаністики, д. і. н., професор Бердянського державного педагогічного університету, e-mail: VNKonst@ukr.net

\section{"НАЦІОНАЛЬНІ ІСТОРІї” ПОЛІЕТНІЧНИХ МІСТ ПІВДЕННОУКРАЇНСЬКОГО ФРОНТИРУ ІМПЕРСЬКОГО ПЕРІОДУ}

В статті аналізуються як практики написання “національних історій” міст Південної України, коли минуле того чи іншого населеного пункту розглядається під кутом зору певного етносу, із акцентуванням уваги на ролі відповідної етнічної групи в історії міста, так і намагання долати обмеження, викликані таким підходом. Стверджується, щзо хоча теза про поліетнічність, а то й мультиетнічність “міського простору" Південної України вже давно стала хрестоматійною і застосовується чи не всіма дослідниками, які звертаються до тих чи інших аспектів міської історії регіону, изе не означає, щзо кожен із изих дослідників розглядає Південь як фронтир, а його міста — як “форпости” на изьому фронтирі; тим більше изе не означає, щзо науковці одностайні в сприйнятті міст Півдня як “плавильних тиглів”, щуо нівелювали національні особливості городян, замінюючи їх іншими ідентичностями. Ключові слова: фронтир, міська історія, історіографія, Південна Україна.

${ }^{1}$ Тернер, Ф. Дж. (2009). Фронтир в американской истории. Москва:

Издательство

"Весь мир", 295-296.

${ }^{2}$ Плохій, С. (2013). Якої історії потребує сучасна Україна? Український історичний журнал, № 3, 4-12.
$\Pi$ ідхід до минувшини Південної України як до історії Степового Кордону, фронтиру поступово набуває все більше прибічників. Багато в чому він $є$ розвитком і перенесенням на місцевий грунт ідей Фредерика Дж. Тернера про фронтир як про рухливу межу між культурами, на якій формувався новий тип “пластичного" суспільства, що не був ні сумою його складових, ані їхнім повним злиттям у плавильному тиглі ${ }^{1}$. Вельми симптоматично, що розмірковуючи над питанням "Якої історії потребує сучасна Україна?”, нині гарвардський професор, а в минулому південноукраїнський (дніпропетровський) науковець Сергій Плохій схиляється до думки, що це має бути ані національна, ані багатоетнічна історія, але історія, в якій Україна розглядається як кордон не тільки між різними державними утвореннями, але і між різними цивілізаційними і культурними зонами. Причому аргументуючи такий підхід, пан Плохій наводить приклади, що переважно стосуються безпосередньо саме теренів степового півдня України ${ }^{2}$.

Відповідний підхід “сповідується” і редколегією альманаху “Фронтири міста”, концепція якого чітко задекларована В. Грибовським ще у анонсі першого випуску: часопис відштовхується від ідеї Фредерика Дж. Тернера, при цьому не зв'язуючи себе

(C) Вікторія Константінова, 2016 
${ }^{3}$ Грибовський, В. Фронтири міста. Avaliable from: http://riurbanhistory.org.ua/projects/39frontiers. [Accessed January 1, 2016].

${ }^{4}$ Див., зокрема: Якубова, Л. (1999). Маріупольські греки (етнічна історія): 1778 р. - початок 30-х років XX ст. К.: Інститут історії України НАНУ; Карамиш, О. М. (2001). Грецьке Родоканакієвське дівоче училище. Наукові праці: Збірник. Миколаїв: Вид-во МФ НАУКМА, Т. 10: Історичні науки, 54-57; Терещук, Н. М. (2006). Метрические книги второй половины XIX в. - источниковая база по изучению истории греческой диаспоры г. Севастополя. Севастополь: взгляд в прошлое. Севастополь, 79-85; Шевякова, Д. П. (2006). Греческое население Севастополя в XIX начале XX в.

Севастополь: взгляд в прошлое. Севастополь, 106-110; Шевякова, Д. П. (2006). Роль греческого населения Севастополя в возрождении православия в Крыму (к. XVIII н. ХХ вв.). Севастополь: взгляд в прошлое. Севастополь, 110-116; Herlihy, P. (1979-1980). Greek Merchants in Odessa in the Nineteenth Century. Harvard Ukrainian Studies. Eucharisterion: Essays presented to Omeljan Pritsak on his Sixtieth Birthday by his Colleagues and Students / Ed. by I. Shevchenko and F. Sysyn. Vol. III-IV, part 1, 399-420. акцентами американської історії, а ставлячи в центр уваги міста степового простору Східної Свропи як складного етнокультурного черезсмужжя, що сформувалося за часів колонізації і зберіглось в подальшому ${ }^{3}$. Концептуально важливо, що часопис свідомо не обмежується висвітленням “фронтирності” якогось одного міста (того ж Дніпропетровська, де він публікується) чи то навіть якогось регіону в рамках нинішніх державних кордонів, тим самим вписуючи історію Південної України (якої зі зрозумілих причин стосується великий відсоток досліджень, вміщених у випусках “Фронтирів міста”, що вже побачили світ) у більш широкий європейський (і не тільки) контекст.

Що ж стосується “міського простору” безпосередньо Південної України, то теза про його поліетнічність, а то й мультиетнічність вже давно стала хрестоматійною і застосовується чи не всіма дослідниками, які звертаються до тих чи інших аспектів міської історії регіону. Але це не означає, що кожен із цих дослідників розглядає Південь як фронтир, а його міста - як “форпости” на цьому фронтирі. Тим більше це не означає, що науковці одностайні в сприйнятті міст Півдня як “плавильних тиглів”, що нівелювали національні особливості городян, замінюючи їх іншими ідентичностями.

Ще за часів Російської імперії була закладена традиція розгляду Півдня як регіону, в якому, при всій його багатоетнічності, провідну роль відігравали російські колонізатори колишнього “Дикого Поля”, яким Південь нібито і має завдячувати за "цивілізацію”. Ця традиція знайшла благодатний грунт, “зрошуваний” імперською ж, а пізніше - і радянською системами. Кинута російським президентом В. Путіним у 2014 р. і очікувано підхоплена російськими пропагандистами теза про “Новоросію” є спробою реанімації саме цієї міфологеми.

В історіографіï кінця XX - початку XXI ст. простежується чітка тенденція посилення уваги до історії окремих етносів у “міському просторі" регіону, до вивчення внеску тієї чи іншої етнічної спільноти у розвиток окремого міста чи більш широких складових “міського простору” Півдня. На сьогодні ми маємо доволі розлогий список досліджень і археографічних праць, що безпосередньо стосуються внеску багатьох етносів у розвиток південноукраїнських міст. Йдеться, зокрема, про греків ${ }^{4}$, євреїв ${ }^{5}$,

${ }^{5}$ Zipperstein, Steven J. (1985). The Jews of Odessa: A Cultural History, 1794-1881. Stanford: Stanford University Press; Шевченко, В. (2007). Участь одеських банкірів єврейського походження у соціальній доброчинності (др. пол. XIX - поч. ХХ ст.). Актуальні питання всесвітньої та зарубіжної історії: Збірник наукових праць. Вип. 10. Харків: ХНУ ім. В.Н. Каразіна, 168-177; Надибська, С. Б. (2003). Євреї та їх роль у підприємництві міст півдня України наприкінці ХIX ст. Науковий вісник Одеського державного економічного університету. № 2 (7), 148-154; Белоусова, Л. Г., Волкова, Т. Е. (2002). Евреи Одессы и Юга Украины: конец XVIII - начало XX вв. Одесса: Студия "Негоциант". 
${ }^{6}$ Самодурова, В. В. (1999). Причорноморські німці. Їх внесок в розвиток м. Одеси та регіону, 1803-1917: Бібліогр. Одеса: Астропринт; Айсфельд, А., Плеська, Е. Г. (2003). Німці Одеси та Одеського регіону: Збірник докладів, зроблених на міжнародних наукових конференціях у Геттінгені. Одеса: Астропринт; Плесская-Зебольд, Э. Г. (1999). Одесские немцы. 1803-1920. Одесса, б. и.

${ }^{7}$ Поляки на півдні України: історія та сьогодення: У 2 т. (2008). Т. 1. Жешов-КиївМиколаїв: Вид-во МДГУ ім. П. Могили. (Серія "Україна: історія і сучасність". Вип. 4).

${ }^{8}$ Калустьян, Л. Х. (1999). Армянская диаспора Одессы. Одесса: Астропринт.

${ }^{9}$ Lampard, E. (1961, Oct.). American Historians and the Study of Urbanization. American Historical Review. LXVII, 50-54, 56, 60.

${ }^{10}$ Warner, Sam B. (1968, October). "If All the World Were Philadelphia: A Scaffolding for Urban History, 17741930". American Historical Review. № 74, 26-43.

${ }^{11}$ Jansen, Harry (2001). The Construction of an Urban Past. Narrative and System in Urban History. Oxford-New York: Berg, 46-50. німців $^{6}$, поляків ${ }^{7}$, меншою мірою - про вірмен ${ }^{8}$. Тут важливу роль зіграли зміни як геополітичної, так і історіографічної ситуації, що мали місце в другій половині 1980-х - на початку 1990-х рр.

Причини підвищення зацікавленості “національними історіями" Південної України слід шукати як в середині самого регіону, так і за його межами: маємо справу, з одного боку, із цілком зрозумілим прагненням представників певних етносів віддати данину пам'яті своїм предкам, які долучились до розбудови Півдня, вписати їхню історію в місцевий контекст; з іншого боку - iз стимулюванням таких досліджень "метрополіями”.

Зрозуміло, що існують також інші фактори, які впливають на рівень зацікавленості у вивченні етнічних аспектів міської історії Півдня, серед яких далеко не останнє місце посідає стан збереженості компактних комплексів джерел з історії представників того чи іншого етносу, а відповідно - і рівень можливостей для відносно швидкого і з найменшими затратами написання наукової роботи, в тому числі - і дисертаційної.

Звичайно, мова не йде про написання "національних історій" міст Півдня як моноетнічних населених пунктів. Натомість маємо справу з тим, що минуле того чи іншого міста розглядається під кутом зору певного етносу, із акцентуванням уваги на ролі відповідної етнічної групи в історії населеного пункту.

Тоді як в багатьох випадках при створенні таких “національних історій” те чи інше південноукраїнське місто розглядається як унікальне (причому часто без належного співвіднесення цієї унікальності з ситуацією в інших містах), стало з'являтися усе більше досліджень, в яких розвиток конкретного міста (а відповідно - і його певної етнічної громади) розглядався з перспективи загального процесу урбанізації.

В цьому аспекті вітчизняні дослідники із великим запізненням торують той шлях, на який їхні “західні” колеги вступили більш ніж півстоліття тому. Достатньо згадати, що поштовхом для виникнення у 1960-х рр. так званої “нової історичної урбаністики" (“new urban history”) стали праці Еріка Лампарда, який саме і зазначав, що всупереч популярному серед істориків жанру написання міських “біографій” варто вивчати не міста як серії “проблем”, а шукати більш прийнятну теорію, аби визначити характерні ознаки "міського” і “неміського". Розвиваючи ідеї Лампарда, його послідовники виступали проти “біографічного методу історико-урбаністичного дослідження”, під яким розумілася дослідницька традиція, “при якій великі та малі міста зображуються як одиниці, кожна з яких має свій власний характер і навіть власну волю”. Критикувався підхід, коли наголос робився на унікальності кожного міста, в результаті чого, як зазначав Сем Варнер, “полиця 3 книгами з історичної урбаністики виглядала як ряд незв’язаних між собою локальних історій”'0. На противагу цьому була висунута концепція, згідно з якою міста - це, перш за все, субсистеми ширших систем ${ }^{11}$.

Надзвичайно показовим найостаннішим прикладом застосування такої концепції на південноукраїнських теренах, який покликаний вписати історію міст регіону у більш широкий контекст, 
є без перебільшення грандіозний проект “Чорне море і його міста-порти, 1774-1914. Розвиток, конвергенції та зв'язки зі світовою економікою”. Він же є вельми цікавим прикладом того, коли при беззаперечній інтернаціональності в проекті доволі чітко проглядає його “національне обличчя". 3 огляду на таку і показовість, і грандіозність, і безпрецедентність доцільно зупинитись на "Чорному морі і його містах-портах...” докладніше.

Мета проекту сформульована як дослідження економічного та соціального розвитку міст-портів Чорноморського регіону (під яким розуміється і Приазовський регіон), що сформували єдиний ринок, який у другій половині XIX - на початку XX ст. став чи не найбільшим світовим експортером зерна. Передбачалося, що при розміщенні в центрі уваги Чорного та Азовського морів і їхніх портів, будуть досліджені історія як самих портових міст, так i прибережних та зв'язаних із ними внутрішніх районів, інтеграція ринків та їх взаємозв'язки зі світовою економікою. Причому це мало бути зроблено поза як історичними, так і нинішніми політичними кордонами.

Виходячи 3 розуміння того факту, що починаючи 3 кінця XVIII ст. берегова лінія Причорноморського регіону перетворилась на міжнародний ринок, пов'язаний із Середземномор'ям, північними європейськими морями, Атлантичним та Індійським океанами, ініціатор і керівник проекту, професор Іонійського університету Тзеліна Харлафтіс (Греція) наголошує, що більш ніж 20 портових міст, які виникли в досліджуваний період на заході, півночі та сході Причорноморського регіону (на сьогоднішній території Болгарії, Румунії, України, Росії, Грузії та Туреччини), стали центрами тяжіння економічної імміграції зі всієї Центральної та Південно-Східної Європи, а “основними агентами економічної інтеграції виявилися мобільні групи так званих людей класичної діаспори, як от греки, євреї і вірмени, а також інших центрально-європейських груп"; саме ці мобільні підприємницькі групи взяли під свій контроль мореплавство, зовнішню торгівлю, а від-

${ }^{12}$ The Project. Avaliable from: http://blacksea.gr/en/project/. [Accessed January 1, 2016]. повідно - і зв'язки зі світовою економікою ${ }^{12}$.

Отже, має місце “замах” на тематику, що за грандіозністю задуму може бути співставлена з броделівськими студіями, присвяченими Середземномор'ю. Звичайно, вітчизняна практика “дисертаціописання” має приклади захисту і з більш грандіозних проблем. Втім, тут - ситуація принципово інша.

Адже реалізацією проекту "Чорне море і його міста-порти, 1774-1914. Розвиток, конвергенції та зв'язки зі світовою економікою" займаються одразу 6 наукових груп, які концентруються навколо 6 грецьких університетів і дослідницьких центрів, якими виступають: Іонійський університет у Корфу, Інститут середземноморських досліджень на Криті, Національний дослідницький фонд у Афінах, Критський університет, Фессалійський університет у Волосі та Егейський університет у Хioci. Представники саме цих інституцій складають ядро проекту, до якого в цілому залучено близько 100 осіб із 11 університетів і дослідницьких центрів Греції і 19 університетів та дослідницьких центрів Туреччини, Болгарії, Румунії, Молдови, України, Росії, Грузії, Італії, Норвегії 
та США. Причому проект (як до речі, і сама історична урбаністика) є міждисциплінарним. При його виконанні використовуються як історичні методи, так і методи з арсеналу географії, економіки, політичних наук, соціології, релігієзнавства, антропології, містобудування та архітектури.

Загалом проектом охоплена історія наступних міст: Одеса, Миколаїв, Ніжин, Херсон, Севастополь, Свпаторія, Феодосія, Керч, Бердянськ, Маріуполь, Таганрог, Ростов-на-Дону, Новоросійськ, Батумі, Стамбул, Трапезунд, Самсун, Сіноп, Гіресун, Варна, Бургас, Констанца, Браїла, Галац.

Як бачимо, 9 з 24 міст розташовані на території Південної України. Із загального контексту, звичайно ж, вибивається Ніжин, який єдиний 3 перелічених 24 населених пунктів навіть за великого бажання не має підстав бути названим містом-портом. Втім, не слід забувати, що саме Ніжин відіграв неабияку роль в історії греків на теренах України імперських часів. Яким чином дослідження історії цього міста прив”язується до проекту “Чорне море і його міста-порти, 1774-1914. Розвиток, конвергенції та зв'язки зі світовою економікою”, доволі прозоро видно вже з теми “Теорія соціальної мережі як інструмент для пояснення розвитку “портових міст" (на прикладі Ніжина)", з якою на першій конференції проекту (“Економічний і соціальний розвиток міст-портів Північного Причорномор'я в кінці XVIII - на початку XX ст.”) виступив Іоанніс Каррас з Іонійського університету в Корфу.

Проект передбачає чотири стадії реалізації.

Перша стадія включала евристичну роботу з виявлення і фіксації неопублікованих і опублікованих джерел з історії кожного міста-порту і Причорноморського регіону в цілому, їхніх зв'язків iз ринками Середземномор'я та Атлантики.

На другій стадії здійснювались обробка зібраних матеріалів, написання по кожному місту-порту близько 100 статей-шаблонів, кожна $з$ яких стосується чітко визначеного аспекту в рамках наступних тематичних блоків: управління; міський ландшафт і географія; порт; культура та громади; економіка та інфраструктура; статистичні дані. Ці статті-шаблони сформували базу даних на кшталт електронної енциклопедії. Зараз триває робота над тим, аби статті-шаблони на сайті проекту були подані в англомовній версії плюс мовою, визначеною базовою для матеріалів, що стосуються того чи іншого морського регіону в рамках Причорномор'я (загалом таких регіонів (“головних портових систем”) спочатку було виокремлено шість, а згодом їх кількість скоротилась до п'яти). Всі бази даних систематизовані відносно: 1) кожного міста-порту; 2) кожного з п'яти морських регіонів; 3) зв'язків із портовими містами Середземного моря і Атлантики.

Третя стадія проекту включала в себе проведення низки дослідницьких воркшопів і конференцій, які мали на меті як координацію роботи різних груп науковців, так і підбиття проміжних підсумків.

Нарешті, четверта стадія, яка наразі триває попри офіційне завершення проекту, передбачає створення комплексу “наукової продукції”, який включатиме, крім безпосередньо інтерактивного 
${ }^{13}$ Methodology. Avaliable from: http://blacksea.gr/methodology/. [Accessed October 8, 2013].

${ }^{14}$ The Project. Avaliable from: http://blacksea.gr/en/project/. [Accessed January 1, 2016].

${ }^{15}$ Грецьке підприємництво і торгівля у Північному Причорномор “ї XVIIIXIX ст. Збірник наукових статей. (2012). К.: Інститут історії України НАН України. веб-сайту “Міста-порти Чорного моря”, і бази даних з тією ж назвою, тринадцятитомник (!) колективних праць та індивідуальних монографій, об'єднаних у загальну “Black Sea History series”.

Вельми показово, що на сайті проекту від початку чітко артикулювалась як одне з його завдань інтернаціоналізація грецьких історичних досліджень за рахунок подолання складностей у зв'язках із університетами та дослідницькими інституціями причорноморських країн, спричинених у тому числі і недостатнім опануванням національних мов. Проект мав на меті і налагодження співпраці грецьких університетів і дослідницьких інституцій із країнами Східної Європи, які належать до Причорноморського регіону, причому спеціально зазначалося, що "Греція має відносну перевагу в порівнянні з іншими країнами СС у іiї тісних зв'язках i відносинах із цією частиною світу з історичних причин". Кінцевою метою проекту заявлена трансформація деяких історичних факультетів (кафедр) грецьких університетів на центри продукування міждисциплінарних знань у співпраці з університетами та дослідницькими інституціями сусідніх країнах Східної Свропи ${ }^{13}$. У цьому ж контексті заслуговує на увагу і така наведена на сайті аргументація щодо актуальності проекту: до недавнього часу доступ до архівів регіону був не те що важким, але майже неможливим через наявність тут різних політичних утворень, різних мов $\mathrm{i}$ домінування в Причорномор'ї Радянського Союзу ${ }^{14}$.

Аби наведені вище моменти були зрозумілішими, не зайве згадати, що проект “Чорне море і його міста-порти, 1774-1914. Розвиток, конвергенції та зв'язки зі світовою економікою” фінансувався Європейським Союзом і Міністерством освіти Греції.

"Національне обличчя" цього проекту проглядає і в тому, що він має передісторію (принаймні, на теренах України) у суто “грецьких проектах"15, ініційованих професором Тзеліною Харлафтіс. I до його реалізації попервах планувалось залучити з українського боку саме дослідників історії греків.

Вельми симптоматично, що на тлі загальної тенденції прагнення написання інших “національних історій” міст Півдня особняком стоїть ситуація із вивченням ролі самого українства у розбудові “міського простору” південноукраїнського регіону.

Південна Україна в історіографічній традиції чітко асоціюється з полікультурним, поліконфесійним регіоном, який упродовж i імперського, і радянського періодів зазнав чи не найбільшої русифікації. I найнаочніше це проявилось у “міському просторі": наприкінці XIX ст. у містах Катеринославщини українців було тільки 27,04 \%, Таврійської губернії - 10,40 \%, Херсонщини - 17,22 \%, тоді як у цілому в губернському населенні їхня частка становила відповідно $68,90 \%, 42,20 \%, 53,48 \%$. Безпосередньо ж у містах Катеринославської губернії українці за чисельністю поступалися росіянам, Херсонської - росіянам та євреям, а Таврійської - росіянам, татарам та євреям. Така ситуація мала вельми драматичний вплив чи не на всі аспекти взаємин міста та села (яке за етнічним складом населення здебільше залишалось українським), а отже - i в цілому на історію регіону. Низький рівень включеності українців у заселення міст і в несільськогосподарську працю, яка є однією $з$ 
16 Турченко, Ф. Г., Турченко, Г. Ф. (2003). Південна Україна: модернізація, світова війна, революція (кінець ХІХ ст. - 1921 р.): Історичні нариси. К.: Генеза, 40-43.

17 Турченко, Ф. Г. (2009). [Рец.]: Присяжнюк Ю. Українське селянство Наддніпрянської України: соціоментальна історія другої половини ХIX початку XX ст. - Черкаси: Вертикаль, 2007. - 637 с. Наукові прачі історичного факультету Запорізького національного університету. Запоріжжя: ЗНУ, вип. XXVII, 397.

${ }^{18}$ Нагорна, Л. (2007). Феномен регіоналізму і національна ідентичність в Україні: історичні витоки. Регіональна історія України. Збірник наукових статей. Випуск 1. К. Ін-т історії НАН України, 117.

19 Довжук, I. В. (2009). Індустріальний Донбас в історії розвитку економіки Наддніпрянської України (друга половина XIX початок XX ст.). Луганськ: вид-во СНУ ім. В. Даля, 256. ознак міського образу життя, можна розглядати як вияв, і в той же час причину того, що місто чи не в кожному аспекті свого існування, попри наявність цілої низки каналів зв'язків, все ж таки великою мірою залишалося “відгородженим” від села. Втім, питання про те, наскільки значущим було це “відгородження”, наскільки “чужим” було місто Південної України в сприйнятті як сільського населення регіону, так і безпосередньо городян-українців, все ще залишається не достатньо з'ясованим.

Значущість проблемності взаємин українства з містом (в тому числі - і містом південноукраїнським) зумовила те, що відповідна тематика не залишилась поза увагою науковців.

3 того факту, що відсоток українців у містах Півдня був низьким, Ф. Г. Турченко і Г. Ф. Турченко роблять висновок, що українці не спромоглися належним чином інтегруватися в міське населення; в результаті урбанізація в регіоні відбувалася за їхньої мінімальної участі ${ }^{16}$.

Як зазначає перший із названих дослідників, бездержавне становище призвело до поглиблення соціокультурного розколу між адміністративно-промисловим містом, де українці становили меншість, і українським селом. Місто було вороже українському селу і селяни неохоче пов’ язували з ним майбутнє; вони “'законсервувалися" у рідному селі ${ }^{17}$.

Утім, такий висновок можна прийняти лише з уточненням, що під містом мається на увазі не населений пункт з відповідним адміністративним статусом, а “істинне місто” в розумінні В. П. Семенова-Тян-Шанського, оскільки процеси, що відбувались у промислових селищах, підпадають саме під ці характеристики. У той же час населення маленьких міст у своєму складі мало значно більший відсоток українців.

Вивчаючи історичні витоки феномена регіоналізму і національної ідентичності в Україні, Л. Нагорна зазначає, що в дореволюційний період на півдні та сході України був закладений фундамент для формування багатонаціонального (а по суті безнаціонального) промислового середовища, в якому активно йшли процеси відмови від традицій і нівелювання особистості; міста ставали осередками російських впливів і російської, у своїй основі, культури, оскільки робоча сила в промисловості формувалася переважно за рахунок “зайшлих” робітників-неукраїнців. Українцям же були притаманні прив’язаність до землі і відраза до життя в урбанізованому середовищі, тож українські родини охочіше виїжджали на необжиті землі, аніж поповнювали лави робітників заснованих поруч з їхніми оселями заводів ${ }^{18}$. До схожих висновків доходить і I. В. Довжук, пишучи, що українці не дуже хотіли працювати на шахтах, тому там і в металургії Донбасу більшість робітників була вихідцями з Росії; невеличким був прошарок українців і серед підприємців - власників цих виробництв; українці ж прагнули працювати на землі ${ }^{19}$.

Відповідна особливість у територіальному розміщенні українців-мігрантів до Південної України відзначена Я. В. Бойком, який пише, що у процесі заселення регіону українці віддавали перевагу сільській місцевості, тоді як росіяни брали активну участь 
${ }^{20}$ Бойко, Я. В. (2009). Розселення переселенців та розміщення представників східнослов'янських етносів у Північному Причорномор'ї (друга половина XIX початок XX ст.). Наукові прачі історичного факультету Запорізького національного університету. Запоріжжя: ЗНУ, вип. XXVII, 49-51, 53.

${ }^{21}$ Гуменюк, А. О. (1993). Міста Правобережної України в другій половині XIX ст.: автореф. дис. на здобуття наук. ступеня канд. іст. наук: спец. 07.00.02 "Вітчизняна історія". Київ, 13.

${ }^{22}$ Herlihy, Patricia. (1981). Ukrainian Cities in the Nineteenth Century. Rethinking Ukrainian History.

Edmonton: The Canadian Institute of Ukrainian Studies. The University of Alberta, 135.

${ }^{23}$ Каппелер, А. (2005). Росія як поліетнічна імперія:

Виникнення. Історія.

Розпад. Львів: Видавництво Українського Католицького Університету, 304. у заселенні та розбудові міст. Причину такої ситуації черкаський дослідник вбачає у тому, що українське селянство у своїй діяльності тривалий час віддавало перевагу землеробству, скотарству та супутнім промислам ${ }^{20}$.

Зауважимо, що ситуація з роллю українців у складі міського населення на півдні України не була унікальною. Тенденції “відставання" рівня урбанізованості українців мали місце і в інших регіонах України, і в цілому в імперії. Досліджуючи етнічний склад населення міст Правобережної України другої половини XIX ст., А. О. Гуменюк дійшов висновку, що інтернаціоналізація міст регіону, який його цікавив, проходила швидше, ніж зростання ролі українства в суспільному і культурному житті цих поселень, а тому міські центри, особливо великі і середні, за своїм культурно-національним змістом залишалися переважно чужими для широкої позаміської округи. При цьому Анатолій Олексійович зауважує, що офіційна статистика все ж давала занижені дані про чисельність українців у містах: просування до вищих і середніх страт суспільства для представників корінної нації було пов'язане з втратою національної ідентичності, а тому при переписах частина городян-українців записувалася росіянами ${ }^{21}$ (між іншим, подібна тенденція досить чітко простежується і на південноукраїнських матеріалах). Розглядаючи причини слабкої участі українців в урбанізації Патриція Герлігі пише про два головні чинники: 1) українці мали переважно сільську ментальність, міцно трималися за землю і при аграрному перенаселенні йшли скоріше на нові землі, а не в міста; 2) російський імперський уряд волів заселяти українські міста росіянами, а не українцями ${ }^{22}$.

Що ж стосується загальноімперської картини, то, за підрахунками, наведеними Андреасом Каппелером, у 1897 р. у цілому по імперії за ступенем урбанізації $(5,61 \%)$ українці пропустили вперед євреїв (49,42 \%), таджиків (29,50\%), німців (23,38 \%), вірмен (23,25\%), сартів (21,06\%), поляків (18,35\%), греків (17,99\%), латишів $(16,05 \%)$, росіян $(15,85 \%)$, естонців $(13,92 \%)$, узбеків $(12,63 \%)$, татар та азербайджанців $(11,29 \%)$, грузинів $(9,41 \%)$, болгар (8,32 \%), румунів (5,72 \%), при цьому випередивши литовців, білорусів, гірські народи Кавказу, якутів, карелів, казахів, башкирів, етноси Середнього Поволжя, бурятів, калмиків, тунгусів і чукчів ${ }^{23}$.

Тож, на нашу думку, коріння “складності взаємин” українців iз містом на півдні України не варто шукати виключно в специфіці ситуації, що мала місце в самому регіоні. Не можна їх зводити i до однієї-двох причин - тут мав місце складний комплекс чинників, який, крім тієї самої селянської ментальності українців, їхньої природної тяги до праці на землі, характеру державної політики, включав економічні кон'юнктури, конкуренцію з боку мігрантів-неукраїнців, рівень підготовленості українського населення до виконання кваліфікованої праці на промислових підприємствах тощо. Що ж до безпосередньо специфіки Південної України, то вона наочно виявилася в тому, що станом на 1897 р. тут частка українців у міському населенні (17,53 \%) була майже вдвічі меншою, ніж у підросійській Україні в цілому (30,35 \%) і це при тому, 
${ }^{24}$ Турченко, Ф. Г., Турченко, Г. Ф. (2003). Південна Україна: модернізація, світова війна, революція (кінець ХІХ ст. - 1921 р.): Історичні нариси. К.: Генеза, 46.

25 Чоп, В. М., Лиман, I. I. (2007). “Вольный Бердянск”: місто в період анархістського соціального експерименту (1918 - 1921 роки). Запоріжжя: РA “Тандем-У”.

${ }^{26}$ Константінова, В. М. (2012). Селяни і місто: феномен сприйняття урбанізаційних процесів у селянській традиції (матеріали історико-археографічних експедицій Північним Приазов’ям). Київ. що частка українців у загальногубернському населенні на Півдні $(56,07$ \%) не різнилася так разюче від показників у інших регіонах України і середнього показника у дев'яти українських губерніях $(73,43$ \%). Одну 3 головних причин такої ситуації варто вбачати в тому, що самі міста в Південній Україні значною мірою носили привнесений характер (між іншим, як була привнесеною сюди і важка промисловість, що складала економічну основу існування промислових селищ), і з часу свого офіційного створення виконували функції форпостів імперської політики в регіоні, який до того знав інші порядки і уклад життя. Сприйняття південним українським селянством міста як “чужого” не зникло і після 1905 р., попри те, що, як зазначають автори монографії “Південна Україна: модернізація, світова війна, революція (кінець ХІХ - 1921 р.)”, в умовах Столипінської реформи відбувалась інтенсивна міграція українців регіону в промислові центри ${ }^{24}$. Досить потужно проявилося таке ставлення південноукраїнського селянства до міста як до “чужого” в “махновському” русі в роки визвольних змагань 25.

Аналіз історіографічного доробку дозволяє констатувати, що до останнього часу науковці у своїх розмірковуваннях і висновках щодо ролі українства у міському житті Півдня спиралися переважно на статистичні джерела. При цьому безпосередньо питання сприйняття українством “неукраїнського міського простору” регіону, попри свою беззаперечну значущість, залишалося на маргінесі наукових зацікавлень. Це зумовлене, зокрема, невирішеністю завдання формування репрезентативної джерельної бази, яка б включала як писемні, так і усноісторичні джерела.

Тож не так давно ми реалізували проект “Образи міст Півдня очима українського населення: специфіка сприйняття українством “неукраїнського міського простору” регіону 1861 - 1933 рр. (за матеріалами усноісторичних експедицій і писемних джерел)”. Важливим кроком на шляху розширення джерельної бази стали підготовка та публікація археографічного видання "Селяни і місто: феномен сприйняття урбанізаційних процесів у селянській традиції (матеріали історико-археографічних експедицій Північним Приазов’ям)"'26. Адже серед 164 старожилів регіону, інтерв'ю яких уміщені у цій книзі, самоідентифікувались як українці $66,46 \%$, тоді як болгарами назвались $15,24 \%$, росіянами $-3,05 \%$, греками - 1,83 \%, білорусами - 1,22 \%. При цьому 10,98 \% респондентів не назвали своєї національності, а 1,22 \% (тобто двоє старожилів) дали такі відповіді: “Батько в мене українець, а мама гречанка. [...] Я хочу стати гречанкою" i "Українка, а батько росіянин. Не знаю, як воно будить”.

Наприкінці хотілося б звернути увагу, що на "національні історії” поліетнічних міст Півдня можна подивитись і під кутом зору, свого часу запропонованим Луїсом Віртом. Розглядаючи гетерогенність населення як необхідну і розпізнавальну ознаку урбанізму, Вірт зазначив, що місто демонструє такий тип і таку ступінь гетерогенності, яку не можна повною мірою пояснити законом великих чисел та адекватно представити за допомогою кривої нормального розподілу, тобто ми маємо справу не просто 3 прямою залежністю рівня відмінностей від чисельності мешкан- 
${ }^{27}$ Вирт, Л. (2005).

Избранные работы по социологии. Сборник переводов. Москва: ИНИОН, 102. ців того чи іншого населеного пункту. Оскільки населення міста не забезпечує власного відтворення, воно рекрутує мігрантів з інших міст, з сільської місцевості своєї держави і з інших країн. Тим самим історично місто було плавильним котлом народів і культур, створюючи сприятливий грунт для виникнення нових “біологічних і культурних гібридів"; воно не лише зазнавало індивідуальних відмінностей, але й заохочувало їх; воно збирало звідусіль людей постільки, оскільки вони різнились і тим самим були корисні один одному, а не на основі їхньої гомогенності і схожості їх мислення ${ }^{27}$.

Вже проглядають певні ознаки того, що як практика написання “національних історій” міст Південної України, так і намагання долати обмеження, викликані таким підходом, знайдуть своє вельми цікаве і великою мірою несподіване продовження та розвиток як у вітчизняній, так і у зарубіжній історіографії. Потужним стимулом для цього служать у тому числі і ті геополітичні зміни останніх двох років, у центрі яких знаходиться саме південноукраїнський регіон з його Кримом і Донбасом.

\section{REFERENCES}

Aisfeld A., Pleska E.H. (2003). Nimtsi Odesy ta Odeskoho rehionu: Zbirnyk dokladiv, zroblenykh na mizhnarodnykh naukovykh konferentsiiakh u Hettinheni. Odesa: Astroprynt.

Belousova L.G., Volkova T.E. (2002). Evrei Odessy i Juga Ukrainy: konec XVIII - nachalo XX vv. Odessa: Studija "Negociant".

Boiko Ia.V. (2009). Rozselennia pereselentsiv ta rozmishchennia predstavnykiv skhidnoslov'ianskykh etnosiv u Pivnichnomu Prychornomor'i (druha polovyna XIX - pochatok XX st.). Naukovi pratsi istorychnoho fakultetu Zaporizkoho natsionalnoho universytetu. Zaporizhzhia: ZNU, vyp. XXVII.

Chop V.M., Lyman I.I. (2007). "Volnyi Berdiansk": misto v period anarkhistskoho sotsialnoho eksperymentu (1918 - 1921 roky). Zaporizhzhia: RA "Tandem-U".

Dovzhuk I.V. (2009). Industrialnyi Donbas v istorii rozvytku ekonomiky Naddniprianskoi Ukrainy (druha polovyna XIX - pochatok XX st.). Luhansk: vyd-vo SNU im. V. Dalia, s. 256.

Herlihy Patricia. (1981). Ukrainian Cities in the Nineteenth Century. Rethinking Ukrainian History. Edmonton: The Canadian Institute of Ukrainian Studies. The University of Alberta, p. 135.

Herlihy P. (1979-1980). Greek Merchants in Odessa in the Nineteenth Century. Harvard Ukrainian Studies. Eucharisterion: Essays presented to Omeljan Pritsak on his Sixtieth Birthday by his Colleagues and Students / Ed. by I. Shevchenko and F. Sysyn. Vol. III-IV, part 1. p. 399-420.

Hretske pidpryiemnytstvo i torhivlia u Pivnichnomu Prychornomor'i XVIII-XIX st. Zbirnyk naukovykh statei. (2012). K.: Instytut istorii Ukrainy NAN Ukrainy.

Hrybovskyi V. (11.01.2016). Frontyry mista (elektronnyi resurs) retrieved from Sait Naukovo-doslidnoho Instytutu istorychnoi urbanistyky: http://ri-urbanhistory.org.ua/projects/39-frontiers

Humeniuk A.O. (1993). Mista Pravoberezhnoi Ukrainy v druhii polovyni XIX st.: avtoref. dys. na zdobuttia nauk. stupenia kand. ist. nauk: spets. 07.00.02 "Vitchyzniana istoriia". Kyiv, s. 13.

Iakubova L. (1999). Mariupolski hreky (etnichna istoriia): 1778 r. - pochatok 30-kh rokiv XX st. K.: Instytut istorii Ukrainy NANU. 
Jansen, Harry (2001). The Construction of an Urban Past. Narrative and System in Urban History. Oxford-New York: Berg, p. 46-50.

Kalust'jan L.H. (1999). Armjanskaja diaspora Odessy. Odessa: Astroprint.

Kappeler A. (2005). Rosiia yak polietnichna imperiia: Vynyknennia. Istoriia. Rozpad. Lviv: Vydavnytstvo Ukrainskoho Katolytskoho Universytetu, s. 304.

Karamysh O.M. (2001). Hretske Rodokanakiievske divoche uchylyshche. Naukovi pratsi: Zbirnyk. Mykolaiv: Vyd-vo MF NAUKMA, T. 10: Istorychni nauky, s. 54-57.

Konstantinova V.M. (2012). Seliany i misto: fenomen spryiniattia urbanizatsiinykh protsesiv u selianskii tradytsii (materialy istoryko-arkheohrafichnykh ekspedytsii Pivnichnym Pryazov'iam). Kyiv.

Lampard E. (1961, Oct.) American Historians and the Study of Urbanization. American Historical Review. LXVII, p. 50-54, 56, 60.

Methodology. Avaliable from: http://blacksea.gr/methodology/. [Accessed October 8, 2013].

Nadybska S.B. (2003). Yevrei ta yikh rol u pidpryiemnytstvi mist pivdnia Ukrainy naprykintsi XIX st. Naukovyi visnyk Odeskoho derzhavnoho ekonomichnoho universytetu. № 2 (7).

Nahorna L. (2007). Fenomen rehionalizmu i natsionalna identychnist $\mathrm{v}$ Ukraini: istorychni vytoky. Rehionalna istoriia Ukrainy. Zbirnyk naukovykh statei. Vypusk 1. K.: In-t istorii NAN Ukrainy.

Plesskaja-Zebol'd Je.G. (1999). Odesskie nemcy. 1803-1920. Odessa, b. i.

Plokhii S. (2013). Yakoi istorii potrebuie suchasna Ukraina? Ukrainskyi istorychnyi zhurnal, № 3, s. 4-12.

Poliaky na pivdni Ukrainy: istoriia ta sohodennia: U 2 t. (2008). T. 1. Zheshov-Kyiv-Mykolaiv: Vyd-vo MDHU im. P. Mohyly. (Seriia "Ukraina: istoriia i suchasnist". Vyp. 4).

Samodurova V.V. (1999). Prychornomorski nimtsi. Yikh vnesok v rozvytok m. Odesy ta rehionu, 1803-1917: Bibliohr. Odesa: Astroprynt.

Shevchenko V. (2007). Uchast odeskykh bankiriv yevreiskoho pokhodzhennia u sotsialnii dobrochynnosti (dr. pol. XIX - poch. XX st.). Aktualni pytannia vsesvitnoi ta zarubizhnoi istorii: Zbirnyk naukovykh prats. Vyp. 10. Kharkiv: KhNU im. V.N. Karazina, s. 168-177.

Shevjakova D.P. (2006). Grecheskoe naselenie Sevastopolja v XIX - nachale XX v. Sevastopol': vzgljad v proshloe. Sevastopol'.

Shevjakova D.P. (2006). Rol' grecheskogo naselenija Sevastopolja v vozrozhdenii pravoslavija v Krymu (k. XVIII - n. XX vv.). Sevastopol': vzgljad v proshloe. Sevastopol'.

Tereshhuk N.M. (2006). Metricheskie knigi vtoroj poloviny XIX v. - istochnikovaja baza po izucheniju istorii grecheskoj diaspory g. Sevastopolja. Sevastopol': Vzgljad v proshloe.

Terner F. Dzh. (2009). Frontir v amerikanskoj istorii. Moskva: Izdatel'stvo "Ves' mir".

The Project (електронний ресурс) retrieved 11.01.2016 from Black Sea Port-cities, 1780s-1910 Web Site: http://blacksea.gr/en/project/

Turchenko F.H. (2009). [Rets.]: Prysiazhniuk Iu. Ukrainske selianstvo Naddniprianskoi Ukrainy: sotsiomentalna istoriia druhoi polovyny XIX - pochatku XX st. — Cherkasy: Vertykal, 2007. — 637 s. Naukovi pratsi istorychnoho fakultetu Zaporizkoho natsionalnoho universytetu. Zaporizhzhia: ZNU, vyp. XXVII.

Turchenko F.H., Turchenko H.F. (2003). Pivdenna Ukraina: modernizatsiia, svitova viina, revoliutsiia (kinets XIX st. - 1921 r.): Istorychni narysy. K.: Heneza.

Virt L. (2005). Izbrannye raboty po sociologii. Sbornik perevodov. Moskva: INION. 
Warner Sam B. (1968, October). "If All the World Were Philadelphia: A Scaffolding for Urban History, 1774-1930”. American Historical Review. № 74, p. 26-43.

Zipperstein Steven J. (1985) The Jews of Odessa: A Cultural History, 1794-1881. Stanford: Stanford University Press.

\section{Константинова Виктория}

\section{«НАЦИОНАЛЬНЫЕ ИСТОРИИ» ПОЛИЭТНИЧЕСКИХ ГОРОДОВ ЮЖНОУКРАИНСКОГО ФРОНТИРА ИМПЕРСКОГО ПЕРИОДА}

В статье анализируются как практики написания "наџчональных историй” городов Южной Украины, когда прошлое того или иного населенного пункта рассматривается под углом зрения определенного этноса, с акиентированием внимания на роли соответствующей этнической группь в истории города, так и попьтки преодолеть ограничения, вызванные таким подходом. Утверждается, что хотя тезис о полиэтничности, а то и мультиэтничности “городского пространства” Южной Украины уже давно стал хрестоматийным и применяется чуть ли не всеми исследователями, обращуающимися к тем или иным аспектам городской истории региона, это не значит, что каждый из этих исследователей рассматривает юг как фронтир, а города - как “форпостыл” на этом фронтире; тем более это не означает, что ученые единодушны в восприятии городов Юга как “плавильных тиглей”, нивелировавших нацииональные особенности горожан, заменяя их другими идентичностями.

Ключевые слова: фронтир, городская история, историография, Южная Украина.

\section{Konstantinova Victoria}

\section{"NATIONAL HISTORIES" OF MULTIETHNIC CITIES OF THE SOUTHERN UKRAINIAN FRONTIER AT THE IMPERIAL PERIOD}

The article examines practices of writing "national histories" of cities of the Southern Ukraine, when the past of a settlement is considered from the perspective of a particular ethnic group, with emphasis on the role of this group in the history of the town (city). At the same time, the attention is paid to attempts of overcoming the limitations caused by this "national" approach. It is argues that although the thesis about multi-ethnicity of the "urban space" of the Southern Ukraine has long been axiomatic and was applied by almost all researchers who studied different aspects of urban history of the region, it does not mean that each of these researchers considered the Southern Ukraine as a frontier, and towns (cities) of the region - as "outposts" of this frontier; moreover it does not mean that researchers are unanimous in their perception of the cities of the South as the "melting pots", which leveled the national characteristics of the townspeople, changing them by other identities.

Keywords: frontier, urban history, historiography, Southern Ukraine. 